\title{
PENGARUH MANAJEMEN MODAL KERJA DAN SOLVABILITAS TERHADAP KINERJA PERUSAHAAN
}

\author{
Sucinia Silfina $^{1)}$ dan Hendra Gunawan ${ }^{2)}$ \\ Program Studi Akuntansi Manajerial, Politeknik Negeri Batam \\ Jl. Ahmad Yani, Batam Centre, Batam 29461, Indonesia \\ ${ }^{1)}$ E-mail: sucinia.silfinakh@gmail.com \\ ${ }^{2}$ E-mail: hendra@polibatam.ac.id
}

\begin{abstract}
Abstrak
Penelitian ini menguji pengaruh manajemen modal kerja dan solvabilitas terhadap kinerja perusahaan manufaktur. Sampel data diambil dari database OSIRIS sebanyak 74 perusahaan manufaktur periode 20102015. Pengaruh variabel independen seperti current ratio, quick ratio, cash ratio dan debt to equity ratio perusahaan secara parsial terhadap return on assets diteliti dengan menggunakan metode analisis data panel. Penelitian ini menunjukkan bahwa current ratio, dan debt to equity ratio berpengaruh dan signifikan terhadap kinerja perusahaan. Quick ratio dan cash ratio tidak memiliki pengaruh yang signifikan terhadap kinerja perusahaan. Penelitian selanjutnya diharapkan menggunakan variabel independen lain dan pengukuran kinerja perusahaan juga dapat diproksikan dengan rasio lain.
\end{abstract}

Kata Kunci: manajemen modal kerja, current ratio, quick ratio, cash ratio, dan debt to equity ratio, return on assets.

\begin{abstract}
This study examines the effect of working capital management and solvency on the performance of manufacturing companies. Data samples were taken from the OSIRIS database of 74 manufacturing companies for the period 2010-2015. The effect of independent variables such as the current ratio, quick ratio, cash ratio and the company's debt to equity ratio partially to return on assets was examined using panel data analysis methods. This study shows that the current ratio, and the debt to equity ratio have an effect on and significantly affect the company's performance. Quick ratio and cash ratio do not have a significant effect on company performance. Future studies are expected to use other independent variables and measurement of company performance can also be proxied by other ratios.
\end{abstract}

Key Words: working capital management, current ratio, quick ratio, cash ratio, debt to equity ratio and return on assets. 


\section{PENDAHULUAN}

Working capital management (WCM) atau manajemen modal kerja adalah salah satu perangkat manajemen yang sangat penting bagi setiap perusahaan untuk meningkatkan pendapatan perusahaannya. Manajemen modal kerja digunakan oleh setiap perusahaan untuk mengelola sumber dan penggunaan dana yang memiliki kaitan dengan modal kerja perusahaan.

Industri merupakan suatu proses pengelolaan bahan baku baik bahan mentah atau bahan setengah jadi agar menjadi barang yang bernilai dan bermanfaat bagi masyarakat. Saat ini perkembangan industri di Indonesia berkembang pesat seiring kemajuan pengetahuan dan teknologi terutama perusahaan industri manufaktur. Hal ini dapat dilihat dari banyaknya perusahaan asing serta perusahaan lokal yang berdiri di Indonesia.

Penelitian Eya (2016) yang menguji pengaruh manajemen modal kerja terhadap kinerja industri makanan dan minuman di Nigeria. Penelitian ini dilakukan dengan melihat pengaruh manajemen modal kerja pada kinerja perusahaan menggunakan Nestle Food Nigeria Plc sebagai sebagai studi kasusnya. Penelitian ini mengukur manajemen modal kerja dengan menggunakan current ratio (CUR), quick ratio (QUR), cash ratio (CAR) dan ukuran kinerja perusahaan diukur menggunakan return on assets (ROA) pada perusahaan Nestle Food Nigeria Plc.

Mengacu pada penelitian Eya (2016) penelitian ini dilakukan untuk meneliti pengaruh antara manajemen modal kerja terhadap kinerja perusahaan industri manufaktur di Indonesia yang terdaftar di database OSIRIS dan menggunakan pengukuran yang sama dengan penelitian sebelumnya yaitu current ratio (CUR), quick ratio (QUR), dan cash ratio (CAR) pada variabel kinerja perusahaan yang diukur menggunakan return on asset (ROA). Perbedaan terjadi pada sampel dan tahun penelitian, serta penambahan variabel independen berupa komponen solvabilitas dengan proksinya debt to equity ratio (DER).

Penelitian sebelumnya menggunakan perusahaan Nestle Food Nigeria Plc sebagai studi kasusnya sedangkan penelitian ini menggunakan sampel perusahaan industri manufaktur di Indonesia yang terdaftar di database OSIRIS karena pada saat ini industri manufaktur di Indonesia sedang mengalami peningkatan. Peneliti menambahkan variabel solvabilitas pada penelitian ini karena dalam menilai manajemen modal kerja sebuah perusahaan, tentunya perlu melihat tingkat solvabilitas perusahaan tersebut. Penelitian sebelumnya menggunakan periode tahun 20042013 sedangkan penelitian ini menggunakan periode tahun 2010-2015 karena data perusahaan di bawah tahun 2016 sudah lengkap dan merupakan tahun periode ter-update.

\section{KAJIAN LITERATUR}

\section{Teori Modigliani Miller (Struktur Modal)}

Tahun 1985 ahli di bidang manajemen keuangan yaitu Modigliani dan Miller (MM) mengajukan teori ilmiah mengenai struktur modal perusahaan yaitu asumsi-asumsi MM tanpa pajak. Pada tahun 1963, Miller mengubah asumsi bahwa terdapat pajak terhadap penghasilan perusahaan (corporate income taxes). Miller kemudian menyimpulkan bahwa penggunaan hutang (leverage) dapat meningkatkan nilai suatu perusahaan diakibatkan biaya bunga hutang sebagai biaya yang mengurangi pembayaran pajak (Atmaja, 2008).

\section{Pecking Order Theory}

Teori ini menjelaskan penyebab perusahaan dalam menentukan hirarki sumber dana yang paling disukainya. Tingkat utang yang kecil bukan karena perusahaan memiliki target utang yang kecil, namun karena perusahaan tidak membutuhkan dana eksternal.

\section{Trade Off Theory}

Teori trade off merupakan alat dalam menyeimbangkan manfaat yang timbul sebagai akibat dari pemanfaatan utang. Berdasarkan teori ini, perusahaan akan melakukan usaha dalam mempertahankan struktur modalnya dengan tujuan memaksimalkan nilai pasar.

\section{Manajemen Modal Kerja}

Modal kerja merupakan dana yang dialokasikan dalam membiayai berbagai kegiatan operasional. Sebagian dari laba yang didapatkan akan dimasukkan kembali sebagai modal perusahaan.

\section{Likuiditas}

Kasus seperti ini dapat memengaruhi kepercayaan yang dimiliki perusahaan dari berbagai pihak yang merupakan modal utama perusahaan dalam mencapai targetnya. Tidak jarang perusahaan 
justru mengalami hal sebaliknya yaitu kelebihan dana, namun hal ini juga tidak baik bagi perusahaan karena berarti manajemen perusahaan tidak mampu untuk memanfaatkan atau mengelola dana yang ada semaksimal mungkin.

\section{Solvabilitas}

Perusahaan dapat menggunakan modal sendiri atau pinjaman sebagai sumber dana. Namun, setiap sumber dana tentunya memiliki kelebihan dan kekurangan. Penggunaan modal dari sumber sendiri memiliki kelebihan diantaranya mudah didapat, persyaratan yang tidak terlalu berat, dan beban pengembalian yang relatif lama serta tidak perlu membayar bunga, angsuran, dan biaya lainnya. Kekurangannya yaitu, jumlah dana yang ada relatif terbatas terutama saat perusahaan membutuhkan dana yang cukup besar.

\section{Kinerja Perusahaan}

Menilai kinerja perusahaan biasanya dilihat dari laba pada laporan keuangan. Melalui penilaian kinerja perusahaan dapat mengevaluasi strategi keuangannya (Gunawan \& Karimah, 2017). Tujuan setiap perusahaan tentunya mendapatkan laba atau keuntungan yang maksimal. Jika sebuah perusahaan mampu memperoleh laba sesuai dengan target perusahaan maka perusahaan tersebut dapat meningkatkan mutu produk dan melakukan investasi baru.

\section{Literatur}

Penelitian yang dilakukan oleh Yusra (2016) yang meneliti pengaruh likuiditas dan solvabilitas terhadap profitabilitas. Sampel dari penelitian ini adalah lima perusahaan di Bursa Efek Indonesia periode 2007-2014. Hasil penelitian menunjukkan bahwa likuiditas statistik tidak signifikan mempengaruhi profitabilitas, berbeda dengan solvabilitas yang secara statistik signifikan profitabilitas.

Penelitian selanjutnya dilakukan oleh Rastanti, Rahayu, \& Sudjana (2014) yang meneliti bagaimana manajemen modal kerja pada perusahaan dan efektivitas manajemen modal kerja guna mengendalikan dan meningkatkan likuiditas perusahaan PT Semen Indonesia (Persero) Tbk. Hasil dari penelitian menunjukkan bahwa analisis rasio likuiditas perusahaan untuk tiga tahun terakhir yaitu pada tahun 2011 sampai dengan tahun 2013 mengalami fluktuasi, pada tahun 2012 mengalami penurunan dan pada tahun 2013 mengalami kenaikan, hal ini menunjukkan bahwa kemampuan perusahaan dalam membayar hutang lancar dengan aktiva lancar yang tersedia masih cenderung tidak stabil.

Hasil penelitian Anggraeni (2015) menunjukkan bahwa current ratio/rasio lancar memiliki pengaruh yang signifikan dengan arah negatif yang berarti jika nilai current ratio meningkat maka akan mengakibatkan nilai return on equity juga ikut meningkat sehingga nilai kinerja perusahaan akan baik. Saat nilai current ratio/rasio lancar mengalami peningkatan, maka hal tersebut dapat menunjukkan semakin besar kemampuan perusahaan untuk memenuhi kewajiban jangka pendeknya, hal ini dapat menunjukkan sebuah perusahaan dapat melakukan penempatan dana yang besar pada sisi aset lancarnya. Penempatan dana yang terlalu besar pada sisi aset lancar akan memiliki dua dampak. Berdasarkan uraian di atas, dapat ditarik hipotesis:

H1 : Current ratio (CUR) berpengaruh terhadap kinerja perusahaan

Hasil penelitian Anggraeni menunjukkan bahwa quick ratio berpengaruh positif terhadap kinerja perusahaan. Hal ini berarti menunjukkan bahwa perusahaan mampu untuk melunasi kewajiban jangka pendeknnya tanpa persediaan sehingga tinggi rasio ini akan semakin baik karena perusahaan diangap mampu untuk membayar kewajibannya. Hasil dari penelitian tersebut yaitu quick ratio berpengaruh signifikan terhadap Kinerja Perusahaan. Berdasarkan uraian di atas, dapat ditarik hipotesis:

H2 : Quick ratio (QUR) berpengaruh terhadap kinerja perusahaan

Penelitian yang dilakukan oleh Eya (2016), rasio kas atau cash ratio (CAR) yang sangat tinggi karena ini merupakan indikasi ketidakmampuan manajemen untuk menginvestasikan uang menganggur menjadi usaha produktif. Alasannya karena sering dianggap sebagai utilisasi aset yang buruk bagi perusahaan untuk memiliki sejumlah besar uang tunai di neraca, karena uang ini dapat dikembalikan ke pemegang saham atau digunakan di tempat lain untuk menghasilkan keuntungan yang lebih tinggi. Dapat disimpulkan bahwa rasio atau cash ratio (CAR) berpengaruh terhadap kinerja perusahaan. Berdasarkan uraian di atas, dapat ditarik hipotesis: 
H3 : Cash ratio (CAR) berpengaruh terhadap kinerja perusahaan

Berdasarkan penelitian yang dilakukan oleh Basit \& Hassan (2017) untuk mengetahui rasio hutang terhadap ekuitas untuk menentukan kinerja perusahaan Pakistan dengan sektor kimia, makanan dan produk perawatan, semen, farmasi, auto assembler dan sektor tekstil. Penelitian dilakukan pada 50 perusahaan yang terdaftar di bawah Bursa Karachi mencakup periode 2010-2014, jumlah observasi dari 250 perusahaan per-tahun. Variabel independen adalah debt to equity dan variabel dependen adalah ukuran, laba per saham, return on asset, return on equity dan pemasaran. Hasil dari penelitian tersebut yaitu debt to equity memiliki pengaruh yang signifikan terhadap return on assets (ROA). Sehingga disimpulkan bahwa debt to assets ratio (DER) berpengaruh terhadap ROA. Berdasarkan uraian di atas, dapat ditarik hipotesis:

H4 : Debt to equity ratio (DER) berpengaruh terhadap kinerja perusahaan

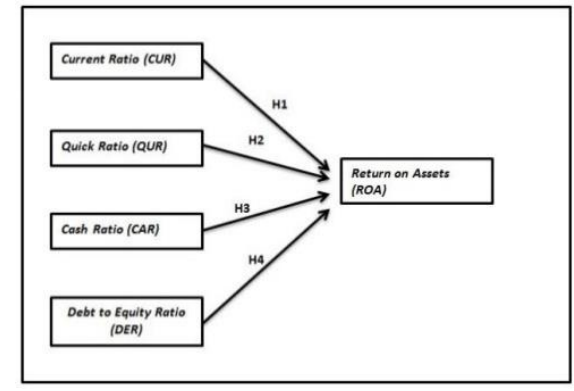

Gambar 1 Model Penelitian

\section{Metode Penelitian}

Jenis dan Sumber Data

Penelitian ini menggunakan jenis data penelitian dengan pendekatan metode kuantitatif. penelitian ini menggunakan metode kuantitatif karena penelitian ini menggunakan data sekunder. Data sekunder merupakan data berupa dokumen atau laporan keuangan perusahaan yang terdaftar di OSIRIS selama periode 2010-2015 yang merupakan data tertulis, yang menunjukkan data perusahaan.

\section{Teknik Penarikan Sampel}

Teknik penarikan sampel yang digunakan penulis dalam penelitian ini adalah dengan menggunakan teknik nonprobabilitas yaitu teknik non random sampling dengan menggunakan metode purposive sampling yang menggunakan metode judgement. Kriteria sampel yang ditetapkan penulis pada penelitian ini adalah: (1) menggunakan sampel perusahaan industri manufaktur di Indonesia yang listing dari database OSIRIS periode 2010-2015, (2) semua data yang diperoleh di dalam laporan keuangan menggunakan mata uang rupiah, (3) memiliki kelengkapan data sesuai apa yang dibutuhkan dalam penelitian ini, (4) periode pelaporan keuangan dilaporkan pada 31 Desember.

Tabel 1 Karakteristik Sampel

\begin{tabular}{lc}
\hline \multicolumn{1}{c}{ Indikasi Perusahaan } & Jumlah \\
\hline \hline Perusahaan manufaktur yang listing di database & 102 \\
OSIRIS tahun 2010-2015 & $(6)$ \\
Perusahaan yang tidak memiliki kelengkapan laporan & \\
Perusahaan manufaktur yang tidak menggunakan & $(22)$ \\
mata uang rupiah (Rp) & 74 \\
\hline Perusahaan yang terpilih menjadi sampel & 444 \\
\hline Total sampel selama periode 6 tahun (2010 - 2015) &
\end{tabular}

\section{Teknik Pengumpulan Data}

Data yang digunakan dalam penelitian ini adalah data sekunder yang diperoleh dari database OSIRIS. Penelitian ini menggunakan pendekatan data panel dengan menggunakan metode pengumpulan data berupa non participant Observation. Data yang dikumpulkan merupakan data yang sudah tersedia dan dilakukan dengan cara observasi data yang diperlukan oleh peneliti untuk menyelesaikan penelitian ini yaitu melakukan penelusuran data laporan keuangan tahunan perusahaan industri manufaktur pada database OSIRIS melalui situs https://wrdsweb.wharton.upenn.edu.

\section{Teknik Pengolahan Data}

Teknik pengolahan data pada penelitian ini adalah dengan mentabulasi hasil data yang telah dihitung. Data yang dihitung didapatkan dari laporan keuangan sesuai dengan apa yang dibutuhkan pada penelitian ini. Data yang sudah didapatkan ditabulasi sesuai keperluan penelitian yang selanjutnya akan dianalisis dengan melakukan analisis statistik dengan menggunakan bantuan alat analisis data yaitu Eviews karena data yang digunakan merupakan data panel.

\section{Analisis Regresi Data Panel}

Data panel adalah gabungan antara data silang (cross section) dan data runtut waktu (time series), di mana unit cross section yang sama diukur pada waktu yang berbeda. Uji Chow bertujuan untuk membandingkan atau memilih model mana yang terbaik antara common effect dan fixed effect. Uji 
Hausman merupakan pengujian statistik untuk memilih apakah model fixed effect atau random effect yang paling tepat digunakan. Asumsi klasik diperlukan untuk mengetahui apakah hasil estimasi regresi yang dilakukan benar-benar bebas dari adanya gejala heteroskedasisitas, gejala multikolinearitas, dan gejala autokorelasi.

\section{1) Uji Multikolinieritas}

Analisis ini digunakan untuk menguji apakah ada hubungan yang sempurna atau hampir sempurna antara variabel bebas, sehingga sulit untuk memisahkan pengaruh antara variabelvariabel itu secara individu terhadap variabel terikat.

\section{2) Uji Heterokedastisitas}

Untuk menguji apakah pada model regresi terjadi ketidaksamaan variance dari residual satu pengamatan ke pengamatan lain. Apabila variance dari residual satu pengamatan ke pengamatan yang lain tetap, maka disebut homoskedastisitas dan jika berbeda disebut heteroskedastisitas.

\section{Uji Hipotesis}

Uji hipotesis merupakan dugaan sementara yang perlu diuji kebenarannya. Jika hipotesis telah diuji dan dibuktikan kebenarannya, maka hipotesis tersebut akan menjadi sebuah teori. Hipotesis berasal dari teori sebuah teori yang sudah ada, kemudian diuji kebenarannya yang nantinya akan memunculkan teori baru. Setelah itu akan dilakukan Uji Signifikansi Simultan (Uji F), Uji Signifikansi Parsial (Uji t), Koefisien Determinasi (R2) dan Adjusted R2.

\section{HASIL DAN PEMBAHASAN}

\section{Statistik Deskriptif}

Tabel 2 menunjukkan bahwa jumlah data yang digunakan dalam penelitian ini berjumlah 444 data sampel. Penelitian ini menguji pengaruh variabel dependen yakni ROA terhadap variabel independen yakni CUR, QUR, CAR, dan DER.

\section{Tabel 2 Statistik Deskriptif}

\begin{tabular}{lccccc}
\hline Variabel & $N$ & Mean & Maximum & Minimum & $\begin{array}{c}\text { Std. } \\
\text { Deviation }\end{array}$ \\
\hline ROA? & 444 & 7,224234 & 42,14000 & $-61,85000$ & 10,21150 \\
CUR? & 444 & 2,246577 & 9,440000 & 0,350000 & 1,613982 \\
QUR? & 444 & 1,562249 & 61,00000 & 0,130000 & 3,099093 \\
CAR? & 444 & 0,571261 & 15,40000 & $-0,320000$ & 1,134110 \\
DER? & 444 & 1,221441 & 11,56000 & $-1,580000$ & 1,458272 \\
\hline
\end{tabular}

Keterangan: Tabel ini mempresentasikan hasil uji statistik. Seluruh hasil dari dari masing-masing variabel adalah dalam bentuk satuan. Variabe dependen (ROA). Variabel Independen (CUR = Current Ratio, QUR = Quick Ratio, $\mathrm{CAR}=$ Cash Ratio, $\mathrm{DER}=$ Debt to Equity Ratio .

Sumber: Output Olahan Eviews 9
Hasil statistik deskriptif pada Tabel 2 menunjukkan nilai return on assets (ROA) mempunyai rata-rata 7,224234 yang menandakan bahwa tingkat pengembalian aset perusahaan manufaktur untuk memperoleh laba periode 2010 2015 berkontribusi sebesar 7,224234. Nilai maksimum menunjukkan nilai tertinggi ROA perusahaan manufaktur sebesar 42,14000 dan nilai minimum yang menunjukkan nilai terendah ROA sebesar -61,85000. Nilai standar deviasi sebesar 10,21150 menunjukkan rata-rata penyimpang ROA.

Current ratio (CUR) merupakan kemampuan perusahaan memenuhi kewajiban jangka pendeknya. Nilai rata-rata CUR perusahaan manufaktur periode 2010-2015 sebesar 2,246577 yang berarti bahwa perusahaan mampu membayarkan utang lancarnya menggunakan aktiva lancar sebanyak 2,24657 dengan menggunakan aset lancarnya, nilai maksimum sebesar 9,440000 dari utang lancar dan nilai minimum sebesar 0,350000. Nilai standar deviasi atau ketimpangannya sebesar 1,613982 menunjukkan rata-rata penyimpangan current ratio, current ratio digunakan untuk melihat kemampuan perusahaan dalam memenuhi atau membayar utang lancar dengan menggunakan aktiva lancar yang dimiliki.

Quick ratio (QUR) mempunyai rata-rata 1,562249 yang berarti bahwa perusahaan yang memiliki total hutang akan menjamin sebesar 1,562249 dari modal sendiri perusahaan. Nilai maksimum sebesar 61,00000 dan nilai minimum sebesar 0,130000. Nilai standar deviasi atau ketimpangannya sebesar 3,099093 menunjukkan rata-rata penyimpangan quick ratio.

Cash ratio (CAR) mempunyai nilai rata-rata sebesar 0,571261 yang menunjukkan perbandingan total hutang lancar yang akan dibayarkan dengan aktiva lancar atau kas perusahaan yang tersedia sebesar 0,571261, nilai maksimum sebesar 15,40000 dan nilai minimum sebesar -0,320000. Nilai standar deviasi atau ketimpangannya sebesar 1,134110 menunjukkan rata-rata penyimpangan cash ratio.

Debt to equity ratio (DER) mempunyai nilai rata-rata sebesar 1,221441 yang menunjukkan ratarata tingkat struktur modal yang diukur dari total liabilitas dibagi dengan total stakeholder. Nilai maksimum sebesar 11,56000 dan nilai minimum sebesar -1,580000. Nilai standar deviasi atau 
ketimpangannya sebesar 1,458272 menunjukkan rata-rata penyimpangan debt to equity ratio.

\begin{tabular}{ccccc}
\multicolumn{5}{c}{ Tabel 3 Uji Chow } \\
\hline Variabel & Effect Test & Statistic & d.f & Prob. \\
\hline CUR? & Cross-section F & 15,441427 & $(73,369)$ & 0,0000 \\
QUR? & Cross-section F & 17,670937 & $(73,369)$ & 0,0000 \\
CAR? & Cross-section F & 15,911614 & $(73,369)$ & 0,0000 \\
DER? & Cross-section F & 16,978557 & $(73,369)$ & 0,0000 \\
\hline Sumber: Output olahan Eviews 9 & & &
\end{tabular}

Berdasarkan Tabel 3 besarnya probabilitas cross-section $\mathrm{F}$ pada variabel CUR adalah sebesar 0,000. Nilai probabilitas cross-section F tersebut < 0,05. Hasil uji Chow tersebut menunjukkan bahwa lebih tepat menggunakan model fixed effect dibandingkan dengan model common effect, maka selanjutnya dilakukan uji Hausman.

Probabilitas cross-section F pada variabel QUR adalah sebesar 0,000. Nilai probabilitas cross-section $\mathrm{F}$ tersebut $<0,05$. Hasil dari uji Chow tersebut menunjukkan bahwa lebih tepat menggunakan model fixed effect dibandingkan dengan model common effect, selanjutnya dilakukan uji Hausman.

Probabilitas cross-section F pada variabel CAR adalah sebesar 0,000. Nilai probabilitas cross-section tersebut $<0,05$. Hasil dari uji Chow tersebut menunjukkan bahwa lebih tepat menggunakan model fixed effect dibandingkan dengan model common effect, selanjutnya dilakukan uji Hausman.

Probabilitas cross-section F pada variabel DER adalah sebesar 0,000. Nilai probabilitas cross-section $\mathrm{F}$ tersebut $<0,05$. Hasil dari uji chow tersebut menunjukkan bahwa lebih tepat menggunakan model fixed effect dibandingkan dengan model common effect, selanjutnya dilakukan uji Hausman.

\section{Tabel 4 Uji Hausman}

\begin{tabular}{ccccl}
\hline Variabel & Effect Test & Statistic & d.f & Prob. \\
\hline CUR? & Cross-section Random & 3,937672 & 1 & 0,0472 \\
QUR? & Cross-section Random & 6,455246 & 1 & 0,0111 \\
CAR? & Cross-section Random & 17,076902 & 1 & 0,0000 \\
DER? & Cross-section Random & 2,295513 & 1 & 0,1297 \\
\hline Sumber: Output & & & &
\end{tabular}

Berdasarkan Tabel 4 besarnya probabilitas cross-section random pada variabel CUR adalah sebesar 0,0472. Nilai probabilitas cross-section random tersebut $<0,05$ maka, hasil uji Hausman menunjukkan bahwa model fixed effect lebih tepat digunakan untuk model persamaan regresi pada hipotesis 1 .

Besarnya probabilitas cross-section random pada variabel QUR adalah sebesar 0,0111. Nilai probabilitas cross-section random tersebut $<0,05$ maka, hasil uji Hausman menunjukkan bahwa model fixed effect lebih tepat digunakan untuk model persamaan regresi pada hipotesis 2 .

Besarnya probabilitas cross-section random pada variabel CAR adalah sebesar 0,0000. Nilai probabilitas cross-section random tersebut $<0,05$ maka, hasil uji Hausman menunjukkan bahwa model fixed effect lebih tepat digunakan untuk model persamaan regresi pada hipotesis 3 .

Besarnya probabilitas cross-section random pada variabel DER adalah sebesar 0,1297. Nilai probabilitas cross-section random tersebut >0,05 maka, hasil uji Hausman menunjukkan bahwa model random effect lebih tepat digunakan untuk model persamaan regresi pada hipotesis 4 .

Tabel 5 Uji Langrange Multiplier

\begin{tabular}{ccccc}
\hline & \multicolumn{3}{c}{ Test Hypothesis } \\
& Cross-section & Time & Both \\
\hline \hline \multirow{2}{*}{ H4 Breusch-Pagan } & $\begin{array}{c}705.1344 \\
\text { Sumber: Output olahan Eviews } 9\end{array}$ & $\begin{array}{l}839.5737 \\
\text { (0.0000) }\end{array}$ & $\begin{array}{l}1544.708 \\
(0.0000)\end{array}$ & $(0.0000)$ \\
\hline Sumber & & &
\end{tabular}

Hasil Tabel 5 pada hipotesis 4 menunjukkan besarnya probabilitas value pada $\mathrm{H} 4$ adalah 0,0000. Nilai probabilitas cross-section random tersebut $>0,05$, maka hasil uji lagrange multiplier menunjukkan bahwa model random effect lebih tepat dibandingkan dengan model common effect.

Tabel 6 Uji Multikolinearitas

\begin{tabular}{|c|c|c|c|c|}
\hline & CUR & QUR & CAR & DER \\
\hline CUR & 1 & 0,345167 & 0,681736 & $-0,373701$ \\
\hline QUR & 0,345167 & 1 & 0,297091 & $-0,155330$ \\
\hline CAR & 0,681736 & 0,297091 & 1 & $-0,261123$ \\
\hline DER & 0,373701 & $-0,155330$ & $-0,261123$ & 1 \\
\hline
\end{tabular}

Tabel 6 menunjukkan bahwa nilai koefisien korelasi antar sesama variabel independen dalam penelitian ini berada pada angka $<0,8$ sehingga dapat disimpulkan bahwa data yang digunakan dalam penelitian ini terbebas dari masalah multikolinieritas.

Tabel 7 Uji Heterokedastisitas

\begin{tabular}{|c|c|c|c|c|}
\hline \multirow{4}{*}{\begin{tabular}{l} 
F-statistic \\
Obs*R-squared \\
Scaled explained SS \\
\multicolumn{1}{c}{ Variable }
\end{tabular}} & \multirow{4}{*}{$\begin{array}{l}1.967746 \\
7.820417 \\
12.19272 \\
\text { Coefficient }\end{array}$} & \multirow{3}{*}{\multicolumn{2}{|c|}{$\begin{array}{l}\text { Prob. F(4,439) } \\
\text { Prob. Chi-Square(4) } \\
\text { Prob. Chi-Square(4) }\end{array}$}} & \multirow{4}{*}{$\begin{array}{l}0.0984 \\
0.0984 \\
0.0160 \\
\text { Prob. }\end{array}$} \\
\hline & & & & \\
\hline & & & & \\
\hline & & Std. Error & t-Statistic & \\
\hline C & 5.745307 & 0.779094 & 7.374344 & 0.0000 \\
\hline CUR & 0.155848 & 0.299617 & 0.520159 & 0.6032 \\
\hline QUR & -0.068670 & 0.115285 & -0.595654 & 0.5517 \\
\hline CAR & 0.588199 & 0.403972 & 1.456038 & 0.1461 \\
\hline DER & -0.195957 & 0.246910 & -0.793637 & 0.4278 \\
\hline
\end{tabular}


Tabel 7 menunjukkan bahwa tidak ada gangguan heterokedastisitas yang terjadi, dimana semua nilai signifikansi $>0,05$ sehingga dapat disimpulkan bahwa model penelitian ini bebas dari gejala heterokedastisitas atau bersifat homokedastisitas.

\section{Pengujian Hipotesis}

Berdasarkan hasil output Eviews pada Tabel 8, maka dapat dibuat model persamaan regresi sebagai berikut:

$\mathrm{ROA}=\alpha+\beta 1$ CURit $+\varepsilon$ it $(\mathrm{H} 1)$

$\mathrm{ROA}=4,575535-1,144764 \mathrm{CUR}+\varepsilon(\mathrm{H} 1)$

Tabel 8 Hasil Uji Model Fixed Effect (H1)

\begin{tabular}{lllll}
\multicolumn{5}{l}{ Dependent variabel: ROA } \\
\multicolumn{1}{c}{ Variabel } & Coeficient & Std.Error & t-Statistic & Prob. \\
\hline \multicolumn{1}{c}{ C } & 4,575535 & 0,841467 & 5,437568 & 0,0000 \\
\multicolumn{1}{c}{ CUR? } & 1,144764 & 0,358149 & 3,196339 & 0,0015 \\
\hline R-squared & 0,787521 & Mean dependent var & 2,035059 \\
Adjusted R-squared & 0,744910 & S.D. dependent var & 3,902962 \\
S.E. of regression & 5,193015 & Sum squared resid & 3999,637 \\
Log likelihood & -1320.340 & Hannan-Quinn criter & 6.558155 \\
F-statistic & 18,48161 & Durbin-Watson stat & 1,058133 \\
Prob(F-statistic) & 0,000000 & & \\
\hline Sumber: Output Olahan Eviews 9 & &
\end{tabular}

Hasil persamaan regresi di atas dapat dilihat nilai konstanta sebesar 4,575535 yang menyatakan bahwa jika variabel current ratio dianggap konstan atau nol, maka nilai probabilitas perusahaan sebesar 4,575535. Koefisien regresi current ratio sebesar 1,144764 menyatakan bahwa jika current ratio meningkat satu satuan, maka probabilitas perusahaan akan menurun sebesar 1,144764. Nilai $R$-squared sebesar 0,787521 mengindikasikan bahwa variabel current ratio hanya mampu menjelaskan variabel terikatnya sebesar 0,787521 sedangkan sisanya dipengaruhi oleh variabel lainnya.

Tabel 8 menunjukkan bahwa variabel current ratio mempunyai nilai sig 0,0015 dan memiliki nilai $t$-Statistic sebesar 3,196339. Nilai signifikan untuk current ratio terhadap return on assets adalah $0,0015<0,05$. Hal ini menunjukkan bahwa perusahaan manufaktur periode tahun 2010-2015 yang terdaftar di database OSIRIS mampu membayar utang lancarnya tanpa mengganggu kegiatan operasional perusahaan.

Berdasarkan hasil output Eviews pada Tabel 9, maka dapat dibuat model persamaan regresi sebagai berikut:

$\mathrm{ROA}=\alpha+\beta 1 \mathrm{QURit}+\operatorname{cit}(\mathrm{H} 2)$
$\mathrm{ROA}=7,120382-0,017171 \mathrm{QUR}+\varepsilon(\mathrm{H} 2)$
Tabel 9 Hasil Uji Model Fixed Effect (H2)

\begin{tabular}{lllll}
\multicolumn{2}{l}{ Dependent variabel: ROA } \\
\hline \multicolumn{1}{c}{ Variabel } & Coeficient & Std.Error & t-Statistic & Prob. \\
\hline \multicolumn{1}{c}{ C } & 7.120382 & 0.289623 & 24.58497 & 0.0000 \\
\multicolumn{1}{c}{ QUR? } & 0.017171 & 0.093788 & 0.183084 & 0.8548 \\
\hline R-squared & 0,781658 & Mean dependent var & 7,147207 \\
Adjusted R-squared & 0,737871 & S.D. dependent var & 10,28188 \\
S.E. of regression & 5,264175 & Akaike info criterion & 6,312536 \\
Sum squared resid & 10225,56 & Schwarn criterion & 7,004398 \\
Log likelihood & $-1326,383$ & Hannan-Quinn criter. & 6,585375 \\
F-statistic & 17,85142 & Durbin-Watson stat & 1,434656 \\
Prob(F-statistic) & 0,000000 & & \\
\hline Sumber: Output Olahan Eviews 9 & &
\end{tabular}

Hasil persamaan regresi di atas dapat dilihat nilai konstanta sebesar 7,120382 yang menyatakan bahwa jika variabel quick ratio dianggap konstan, maka nilai profitabilitas perusahaan sebesar 7,120382. Koefisien regresi quick ratio sebesar 0,017171 menyatakan jika quick ratio meningkat satu satuan, maka profitabilitas perusahaan akan menurun sebesar 0,017171. Nilai $R$-squared sebesar 0,781658 mengindikasikan bahwa variabel quick ratio mampu menjelaskan variabel terikatnya sebesar 0,781658 sedangkan sisanya dipengaruhi oleh variabel lain.

Tabel 9 menunjukkan variabel quick ratio mempunyai nilai sig 0,8548 dan memiliki nilai tStatistic sebesar 0,183084. Nilai signifikan untuk quick ratio terhadap return on assets adalah 0,8548 $>0,05$. Hal ini menunjukkan bahwa perusahaan manufaktur periode tahun 2010-2015 yang terdaftar di database OSIRIS tidak mampu membayar kewajiban jangka pendek dengan memakai aktiva lancar, tanpa mengandalkan terjualnya persediaan. Hasil penelitian ini sesuai dengan penelitian yang dilakukan oleh Devi (2013) yang mendapatkan hasil bahwa secara parsial quick ratio tidak berpengaruh terhadap return on assets. Apabila terdapat perbedaan yang sangat besar, misal current ratio meningkat sedangkan quick ratio menurun, maka terjadi investasi yang besar pada persediaan perusahaan.

Tabel 10 Hasil Uji Model Fixed Effect (H3)

\begin{tabular}{lclll}
\multicolumn{5}{l}{ Dependent variabel: ROA } \\
\hline \multicolumn{1}{c}{ Variabel } & Coeficient & Std.Error & t-Statistic & Prob. \\
\hline C & 7,188203 & 0,320490 & 22,42877 & 0,0000 \\
\multicolumn{1}{c}{ CAR? } & $-0,071871$ & 0,351949 & $-0,204210$ & 0,8383 \\
\hline R-squared & 0,781662 & Mean dependent var & 7,147207 \\
Adjusted R-squared & 0,737876 & S.D. dependent var & 10,28188 \\
S.E. of regression & 5,264116 & Akaike info criterion & 6,312514 \\
Sum squared resid & 10225,33 & Schwarz criterion & 7,004376 \\
Log likelihood & $-1326,378$ & Hannan-Quinn criter. & 6,585353 \\
F-statistic & 17,85193 & Durbin-Watson stat & 1,437861 \\
Prob(F-statistic) & 0.000000 & & \\
\hline Sumber: Output olahan Eviews 9 & &
\end{tabular}

Berdasarkan hasil output Eviews pada Tabel 4.10, maka dapat dibuat model persamaan regresi sebagai berikut:

$\mathrm{ROA}=\alpha+\beta 1 \mathrm{CARit}+\varepsilon$ it $(\mathrm{H} 3)$

$\mathrm{ROA}=7,188203-0,071871 \mathrm{CAR}+\varepsilon(\mathrm{H} 3)$ 
Hasil persamaan regresi di atas dapat dilihat nilai konstanta sebesar 7,188203 yang menyatakan bahwa jika variabel cash ratio dianggap konstan, maka nilai profitabilitas perusahaan sebesar 7,188203. Koefisien regresi cash ratio sebesar 0,071871, menyatakan jika cash ratio meningkat satu satuan, maka profitabilitas perusahaan akan menurun sebesar 0,071871. Nilai $R$-squared sebesar 0,781662 mengindikasikan bahwa variabel cash ratio mampu menjelaskan variabel terikatnya sebesar $78 \%$ sedangkan sisanya dipengaruhi oleh variabel lain.

Tabel 10 variabel quick ratio mempunyai nilai sig 0,8383 dan memiliki nilai t-Statistic sebesar 0,204210. Nilai signifikan untuk cash ratio terhadap return on assets adalah 0,8383>0,05. Hal ini menunjukkan bahwa perusahan manufaktur periode tahun 2010-2015 yang terdaftar di OSIRIS mengalami kendala dalam memenuhi utangutangnya. Hasil penelitian ini sesuai dengan hasil penelitian yang dilakukan oleh Afrinda (2013) yang mendapatkan hasil bahwa cash ratio tidak berpengaruh signifikan terhadap profitabilitas perusahaan makanan dan minuman yang terdaftar di Bursa Efek Indonesia periode 2006-2012.

Tabel 11 Hasil Uji Model Random Effect (H4)

\begin{tabular}{lllll}
\multicolumn{5}{l}{ Dependent variabel: ROA } \\
\hline Variabel & Coeficient & Std.Error & t-Statistic & Prob. \\
\hline C & 8,647974 & 1,069876 & 8,083159 & 0,0000 \\
\multicolumn{1}{c}{ DER? } & $-1,229003$ & 0,281750 & $-4,362038$ & 0,0000 \\
\hline R-squared & 0,041156 & Mean dependent var & 1,732427 \\
Adjusted R-squared & 0,038987 & S.D. dependent var & 5,285792 \\
S.E. of regression & 5,181730 & Sum squared resid & 11867,85 \\
F-statistic & 18,97177 & Durbin-Watson stat & 1,184825 \\
Prob(F-statistic) & 0,000000 & & \\
\multicolumn{4}{l}{ Sumber: Output olahan Eviews 9}
\end{tabular}

Berdasarkan hasil output Eviews pada Tabel 11, maka dapat dibuat model persamaan regresi sebagai berikut:

$\mathrm{ROA}=\alpha+\beta$ 1DERit + cit $(\mathrm{H} 4)$

$\mathrm{ROA}=8,647974-1,229003+\varepsilon(\mathrm{H} 4)$

Hasil persamaan regresi di atas dapat dilihat nilai konstanta sebesar 8,647974 yang menyatakan bahwa jika variabel debt to equity ratio dianggap konstan, maka nilai profitabilitas perusahaan sebesar 8,647974. Koefisien regresi debt to equity ratio sebesar 1,229003 menyatakan jika debt to equity ratio meningkat satu satuan, maka profitabilitas perusahaan akan menurun sebesar -1,229003. Nilai $R$-squared sebesar 0,041156 mengindikasikan bahwa variabel debt to equity ratio mampu menjelaskan variabel terikatnya sebesar 0,041156 sedangkan sisanya dipengaruhi oleh variabel lain.

Tabel 11 variabel debt to equity ratio mempunyai nilai sig 0,0000 dan memiliki nilai tStatistic sebesar -4,362038. Nilai signifikansi untuk debt to equity ratio terhadap return on assets adalah $0,0278<0,05$. Hal ini menunjukkan bahwa perusahaan manufaktur periode tahun 2010-2015 yang terdaftar di OSIRIS mampu memenuhi kewajiban saat perusahaan dilikuidasi. Semakin tinggi debt to equity ratio akan mengakibatkan penurunan pada profitabilitas perusahaan. Semakin rendah rasio ini maka semakin sedikit kewajiban perusahaan di masa yang akan datang.

\section{Analisis Data}

Hasil uji statistik yang telah dijelaskan pada Tabel 12 menunjukkan terdapat pengaruh yang signifikan antara current ratio dengan kinerja perusahaan yang diukur dengan ROA. Hal ini menyatakan bahwa hipotesis pertama (H1) terdukung. Hasil ini sesuai dengan penelitian yang dilakukan oleh Siallagan \& Ukhriyawati (2016), rasio likuiditas yang diproyeksikan oleh current ratio (CUR) berpengaruh positif dan signifikan terhadap kinerja keuangan. Hasil penelitian ini berbeda dengan penelitian yang dilakukan oleh Putry \& Erawati, (2013) yang mendapatkan hasil bahwa variabel current ratio tidak berpengaruh terhadap kinerja keuangan (return on assets) pada perusahaan manufaktur yang terdaftar di Bursa Efek Indonesia.

Tabel 12 Hasil Uji Statistik

\begin{tabular}{|c|c|c|c|c|}
\hline & Hipotesis & Prob & $t$-Statistic & Hasil \\
\hline $\mathrm{H} 1$ & $\begin{array}{l}\text { Current ratio berpengaruh } \\
\text { terhadap kinerja perusahaan (ROA) }\end{array}$ & 0,0015 & 3,1963 & Terdukung \\
\hline $\mathrm{H} 2$ & $\begin{array}{l}\text { Quick ratio berpengaruh terhadap } \\
\text { kinerja perusahaan (ROA) }\end{array}$ & 0,8548 & 0,1830 & Tidak Terdukung \\
\hline H3 & $\begin{array}{l}\text { Cash ratio berpengaruh terhadap } \\
\text { kinerja perusahaan (ROA) }\end{array}$ & 0,8383 & $-0,2042$ & Tidak Terdukung \\
\hline $\mathrm{H} 4$ & $\begin{array}{l}\text { Debt to equity ratio berpengaruh } \\
\text { terhadap kinerja perusahaan (ROA) }\end{array}$ & 0,0000 & $-4,3620$ & Terdukung \\
\hline
\end{tabular}

Semakin besar ROA suatu perusahaan akan menunjukkan kinerja yang semakin baik, karena tingkat pengembalian semakin besar. Current ratio berpengaruh terhadap ROA menunjukkan bahwa kewajiban jangka pendek perusahaan dapat mempengaruhi tingkat profitabilitas perusahaan, perusahaan yang tidak mampu memenuhi 
kewajiban jangka pendeknya akan dikenai beban tambahan atas kewajibannya.

Hasil uji statistik yang telah dijelaskan pada Tabel 12 menunjukkan adanya pengaruh yang signifikan antara quick ratio dengan kinerja perusahaan yang diukur dengan ROA. Hal ini menunjukkan bahwa hipotesis kedua $(\mathrm{H} 2)$ tidak terdukung. Hasil penelitian ini sesuai dengan hasil penelitian yang dilakukan oleh Devi (2013) bahwa secara parsial quick ratio tidak berpengaruh signifikan terhadap return on assets (ROA) tetapi net profit margin dan firm size berpengaruh terhadap return on assets. Hasil ini berbeda dengan penelitian yang dilakukan oleh Anggraeni (2015), yang menyatakan bahwa quick ratio berpengaruh positif terhadap kinerja perusahaan yang berarti bahwa perusahaan mampu untuk melunasi kewajiban jangka pendeknya. Rasio ini akan semakin baik karena perusahaan dianggap mampu untuk membayar kewajibannya.

Hasil uji statistik yang telah dijelaskan pada Tabel 12 menunjukkan adanya pengaruh yang signifikan antara cash ratio dengan kinerja perusahaan yang diukur dengan ROA. Hal ini menunjukkan bahwa hipotesis ketiga (H3) tidak terdukung. Hasil ini sesuai dengan penelitian yang dilakukan oleh Afrinda (2013), yang mendapatkan hasil bahwa variabel cash ratio secara parsial berpengaruh negatif namun tidak signifikan terhadap profitabilitas (ROA) perusahaan makanan dan minuman yang terdaftar di Bursa Efek Indonesia (BEI) periode 2006-2012. Penelitian ini berbeda dengan penelitian yang dilakukan oleh Eya (2016), yang mendapatkan hasil bahwa terdapat pengaruh yang signifikan antara cash ratio terhadap kinerja perusahaan (ROA).

Hasil uji statistik yang telah dijelaskan pada Tabel 12 menunjukkan terdapat pengaruh yang signifikan antara debt to equity ratio terhadap kinerja perusahaan yang diukur ROA. Hal ini menunjukkan bahwa hipotesis keempat (H4) terdukung. Hasil ini sesuai dengan penelitian yang dilakukan oleh Dewi \& et. al (2015), yang mendapatkan hasil bahwa ada pengaruh negatif dan signifikan secara parsial dari DER terhadap ROA pada perusahaan perbankan yang terdaftar di Bursa Efek Indonesia tahun 2011-2013.

Hasil Penelitian yang dilakukan oleh Sari \& Budiasih (2014) sesuai dengan penelitian ini, yang mendapatkan hasil yaitu debt to equity ratio mempunyai pengaruh signifikan pada profitabilitas di perusahaan wholesale and retail trade. Tinggi rendahnya DER akan mempengaruhi tingkat pencapaian ROA perusahaan. Biaya yang ditimbulkan oleh pinjaman lebih kecil daripada biaya modal sendiri, maka sumber dana yang berasal dari pinjaman atau hutang akan lebih efektif dalam menghasilkan laba dan sebaliknya jika biaya pinjaman lebih besar daripada biaya modal sendiri, maka sumber dana yang berasal dari pinjaman atau hutang kurang efektif dalam menghasilkan laba. Kinerja perusahaan dapat dipengaruhi oleh bebagai faktor seperti dalama penelitian Gunawan \& Ramadhani (2018) dan Gunawan \& Serlyna (2018).

\section{PENUTUP}

\section{Simpulan}

Penelitian ini bertujuan untuk meneliti mengenai pengaruh current ratio, quick ratio, cash ratio, dan debt to equity ratio terhadap return on assets. Periode pengamatan dalam penelitian ini adalah tahun 2010-2015 dengan 444 perusahaan manufaktur yang memenuhi syarat untuk dijadikan sampel dalam penelitian ini, berdasarkan hasil analisis dapat ditarik kesimpulan sebagai berikut:

Rasio likuiditas yang diproksikan oleh variabel current ratio berpengaruh signifikan terhadap kinerja perusahaan (return on assets). Rasio likuiditas yang diproksikan oleh quick ratio tidak berpengaruh terhadap kinerja perusahaan (return on assets). Rasio likuiditas yang diproksikan oleh cash ratio tidak berpengaruh terhadap kinerja perusahaan (return on assets). Rasio solvabilitas yang diproksikan oleh debt to equity ratio berpengaruh signifikan terhadap kinerja perusahaan (return on assets).

\section{Keterbatasan}

Penelitian ini terdapat beberapa keterbatasan, antara lain: pertama, analisis sampel yang digunakan hanya terbatas menggambarkan perusahaan manufaktur saja. Kedua, penelitian ini hanya menggunakan empat variabel independen, kemungkinan besar banyak variabel lain yang mempengaruhi profitabilitas. Ketiga, kinerja perusahaan pada penelitian ini hanya dilihat dari profitabilitasnya yang diproksikan oleh return on assets. 


\section{Implikasi}

Penelitian ini berimplikasi kepada perusahaan dan investor. Pertama bagi perusahaan sebaiknya lebih memperhatikan periode penagihan piutang dan siklus konversi kas sehingga perusahaan dapat menerima kembali kas untuk operasional perusahaan. selain piutang perusahaan juga harus memperhatikan periode pembayaran utang kapan utang tersebut dapat diselesaikan mengingat bahwa utang perusahaan dapat mempengaruhi kepercayaan pemasok terhadap perusahaan. Kedua, bagi investor dapat melihat perputaran modal kerja melalui penelitian ini, sehingga investor dapat melihat dan menganalisis perusahaan mana yang telah menggunakan modal kerjanya secara efektif dan efisien, sehingga investor dapat menentukan perusahaan mana yang akan menjadi tujuan investasi yang tepat.

\section{Saran}

Penelitian selanjutnya diharapkan dapat menggunakan faktor-faktor lain seperti, cash turn over ratio, inventory to working capital ratio, cash to operating expense ratio, working capital to total assets ratio yang mungkin berpengaruh terhadap kinerja perusahaan dengan menambah untuk tahun pengamatan. Penelitian selanjutnya sebaiknya mempertimbangkan penggunaan variabel quick ratio, karena persediaan merupakan aktiva lancar yang nilainya cukup besar dan melibatkan modal kerja yang besar. Sistem persediaan yang baik dapat meningkatkan profitabilitas perusahaan, sementara sistem persediaan yang buruk dapat mengikis laba dan menjadikan bisnis kurang kompetitif.

\section{Daftar Pustaka}

A. Afrinda, N. (2013). Analisis Pengaruh Likuiditas dan Solvabilitas terhadap Profitabilitas pada Perusahaan Makanan dan Minuman yang Terdaftar di Bursa Efek Indonesia (BEI). Diambil kembali dari www.academia.edu.

B. Anggraeni, D. (2015). Pengaruh Current Ratio, Quick Ratio, Debt to Equity Ratio dan Ukuran Perusahaan Terhadap Kinerja Perusahaan. Jurnal Akuntansi dan Keuangan, 4, 41-60.

C. Atmaja, L. S. (2008). Teori dan Praktik Manajemen Keuangan. Yogyakarta: Penerbit Andi.
D. Basit, A., \& Hassan, Z. (2017). Impact of Capital Structure on Firms Performance: A study on Karachi Stock Exchange (KSE) Listed Firms in Pakistan. International Journal of Management, Accountiing and Economics , 4, 118-135.

E. Devi, M. (2013). Faktor-faktor yang Mempengaruhi Profitabilitas pada Perusahaan Kimia \& Farmasi yang terdaftar di Bursa Efek Indonesia Tahun 2008-2011. Repositori UMRAH. Diambil kembali dari Jurnal Umrah.

F. Dewi, N., Cipta, \& Kirya. (2015). Pengaruh LDR, LAR, DER, dan CR terhadap ROA. $e$ Journal Bisma Universitas Pendidikan Ganesha, 3.

G. Eya, C. I. (2016). Effect of Working Capital Management on the Performance of Food and Beverage Industries in Nigeria. Arabian Journal of Business and Management Review, 6(5), 1-7.

H. Gunawan, H., \& Karimah, H. (2017). The Six Sigma Approach for the Development of Accounting Information System Performance. Journal of Applied Accounting and Taxation, 2(1), 15-21. doi:10.5281/zenodo.1306525

I. Gunawan, H., \& Ramadhani, W. (2018). How Intellectual Capital Effects Firm's Financial Performance. Journal of Applied Accounting and Taxation, 3(1), 1-8. doi:10.5281/zenodo. 1304936

J. Gunawan, H., \& Serlyna, S. (2018). Impact of Information Technology Investment to Financial Performance on Banking Sector. Journal of Applied Managerial Accounting, 2(1), 41-46. doi:10.30871/jama.v2i1.700

K. Putry, N. C., \& Erawati, T. (2013, Desember). Pengaruh Current Ratio, Total Assets Turnover, dan Net Profit Margin, terhadap Return On Assets. Jurnal Akuntansi, 1, 22-34.

L. Rastanti, C. A., Rahayu, M. S., \& Sudjana, N. (2014). Manajemen Modal Kerja yang Efektif Sebagai Upaya Meningkatkan dan Mengendalikan Likuiditas. Jurnal Administrasi Bisnis, 15, 1-9.

M. Sari, N. V., \& Budiasih, I. (2014). Pengaruh Debt to Equity Ratio, Firm Size, Inventory Turnover dan Assets Turnover pada Profitabilitas. E-Jurnal Akuntansi Universitas Udayana, 261-273.

N. Siallagan, H. A., \& Ukhriyawati, C. F. (2016). Pengaruh Solvabilitas, dan Aktivitas terhadap Kinerja Keuangan pada Perusahaan Rokok yang 
terdaftar di Bursa Efek Indonesia tahun 20102014. Bening Journal.

O. Yusra, I. (2016). Kemampuan Rasio Likuiditas dan Solvabilitas dalam Memprediksi Laba Perusahaan: Studi Empiris pada Perusahaan Telekomunikasi yang Terdaftar di Bursa Efek Indonesia. Jurnal Benefita, 15-23. 